\title{
Characterizations of Gelatin from the Skin of American Bullfrog (Rana catesbeiana) as Affected by Extraction Temperature
}

\author{
Weibo Zhang, Chong Chen, Ziyu Huang and Pengjie Wang *
}

check for updates

Citation: Zhang, W.; Chen, C.; Huang, Z.; Wang, P. Characterizations of Gelatin from the Skin of American Bullfrog (Rana catesbeiana) as Affected by Extraction Temperature. Sustainability 2021, 13, 4390 . https://doi.org/10.3390/ su13084390

Academic Editor: Nelson G. M. Gomes

Received: 23 February 2021

Accepted: 31 March 2021

Published: 15 April 2021

Publisher's Note: MDPI stays neutral with regard to jurisdictional claims in published maps and institutional affiliations.

Copyright: (c) 2021 by the authors. Licensee MDPI, Basel, Switzerland. This article is an open access article distributed under the terms and conditions of the Creative Commons Attribution (CC BY) license (https:// creativecommons.org/licenses/by/ $4.0 /)$.
Department of Nutrition and Health, Beijing Higher Institution Engineering Research Center of Animal Product, College of Food Science \& Nutritional Engineering, China Agricultural University, Beijing 100083, China; zhangweibo@cau.edu.cn (W.Z.); chenchong409@cau.edu.cn (C.C.); huangziyu@cau.edu.cn (Z.H.)

* Correspondence: wpj1019@cau.edu.cn; Tel.: +86-010-6273-6348

Abstract: We investigated the effect of extraction temperature on the gel properties of gelatin from the skin of the American bullfrog (Rana catesbeiana) and the mechanisms. The textural and rheological properties of bullfrog gelatin extracted at $45^{\circ} \mathrm{C}(\mathrm{G} 45), 55{ }^{\circ} \mathrm{C}(\mathrm{G} 55)$, and $65{ }^{\circ} \mathrm{C}$ (G65) were measured. The molecular weight distributions, microstructures, and amino acid compositions of the bullfrog gelatins were also determined. G45, G55, and G65 had gel strengths of 272.1, 225.6, and $205.8 \mathrm{~g}$ and hardness values of 28.1, 24.0, and $22.5 \mathrm{~N}$, respectively. The gelling temperatures ranged from 19.3 to $23.9^{\circ} \mathrm{C}$, and the melting temperatures ranged from 28.9 to $31.5^{\circ} \mathrm{C}$. All the results were compared with those of commercial porcine gelatin. We propose that the higher gel strength of G45 with a higher band intensity of $\alpha 2$-chains compared with G55 and G65 was more likely to form ordered and strong cross-links. The gelatin extracted at a lower temperature (G45) had a finer gel structure, suggesting that it would be more difficult to disrupt by applied force. Gelatin extracted at a lower temperature demonstrated better properties with $\alpha 2$-chains and a fine gel structure. These results provide basic information on the extraction of American bullfrog skin gelatin for industrial applications.

Keywords: American bullfrog; textural properties; gel structures

\section{Introduction}

Gelatin is a fibrous protein hydrolyzed from a collagen that is mainly derived from the skin, connective tissues, and bones of animals [1]. Gelatin has been widely used as a stabilization, gelation, and emulsion agent in food and non-food industries [2,3]. The world usage of gelatin is about 200,000 metric tons yearly [4], which is predominantly manufactured from the skin and bones of pigs and cows. However, the outbreaks of foot-and-mouth ailments and bovine spongiform encephalopathy (BSE) have caused panic among customers [5].

Recently, chicken skin [6], chicken deboner residue [7], duck feet [8], camel skins [9], goat skin [10], cod fish skin [11,12], salmon fish skin [13], and shark byproducts [14] as additional sources have been tapped for gelatin extraction in attempts to increase safety. American bullfrogs (Rana catesbeiana) may be a new and safe source of gelatin with no threat of BSE. In China, the bullfrog annual production currently exceeds 100,000 tons, which is processed into products with no skin [15]. Gelatin can be extracted from different species of frogs in the genus Rana, such as Rana tigerina [2], Rana nigromaculata [16], and Rana esculanta [17].

The American bullfrog (Rana catesbeiana) is an important economic amphibian and one of the largest frogs in the genus Rana [15]. As bullfrog meat has developed in international gastronomy in various styles [18], the hatcheries of American bullfrogs have increased all around the world [19], generating a great amount of skin as by-products. Extracting gelatin from American bullfrog skin can reduce waste in the bullfrog industry and increase the 
revenue for the processor and farmer. However, there are no reports on the production of gelatin from American bullfrogs and details on the gel properties.

Gel properties (gel strength) are critical indices for evaluating the quality of gelatin [17]. The raw material, pretreatment, and extraction conditions (the $\mathrm{pH}$, time, and particularly temperature) can influence the properties of gelatin $[20,21]$. Changing the extraction temperatures can cause different degrees of gelatin degradation, which leads to different molecular weight distributions [22]. The molecular weight distributions and amino acid composition were reported as important factors that affected the gel properties of gelatin [9]. However, to the best of our knowledge, the effects of extraction temperature on the characteristics of American bullfrog gelatin have not yet been evaluated.

American bullfrog skin may represent a good source for gelatin extraction due to its abundance, low cost, and safety. In this study, we aimed to characterize the gelatin extracted from American bullfrog skin at various extraction temperatures to provide basic information regarding American bullfrog skin gelatin for potential industrial applications.

\section{Materials and Methods}

\subsection{Materials}

American bullfrog skin was obtained from restaurant scrap (Beijing, China) and stored at $-20^{\circ} \mathrm{C}$ for no longer than 3 months until further use. High molecular weight markers (5-245 kDa) were bought from Beijing Solarbio Science \& Technology Co., Ltd. (Beijing, China). Porcine skin gelatin (type A) was obtained from Sigma Aldrich Inc., (St. Louis, MO, USA) (V900863). All other chemicals used were of analytical grade.

\subsection{Extraction of Gelatin from Bullfrog Skin}

Bullfrog skin gelatin was extracted using the procedure described by Hafsteinsson et al. [23] with some modifications. The bullfrog skins were first cleaned to eliminate all residues of muscle then cut into small pieces $(2 \times 3 \mathrm{~cm})$. The skin was soaked in $0.1 \mathrm{~mol} \cdot \mathrm{L}^{-1}$ $\mathrm{NaOH}$ solution $1: 10(w / v)$ below $10^{\circ} \mathrm{C}$ for $3 \mathrm{~h}$, followed by washing with water until the wash water was almost neutral. The skin was soaked in $0.05 \mathrm{~mol} \cdot \mathrm{L}^{-1} \mathrm{CH}_{3} \mathrm{COOH}$ solution 1:10 (w/v) under gentle stirring below $10^{\circ} \mathrm{C}$ for $3 \mathrm{~h}$. This was followed by washing with water until the wash water was almost neutral. Extractions with water 1:6 $(w / v)$ were stirred for $6 \mathrm{~h}$ at 45,55 , and $65^{\circ} \mathrm{C}$ The gelatin samples were filtered by cheesecloth and then centrifuged at $1589 \times g$ for $10 \mathrm{~min}$. The supernatant was freeze-dried.

\subsection{Determination of the Yield and Proximate Composition}

\subsubsection{Yield Determination}

The yield of gelatin was calculated based on the following equation:

$$
\text { yield }(\%)=\frac{\text { Weight of freeze dried gelatin }(\mathrm{g})}{\text { Weight of initial skin }(\mathrm{g})} \times 100
$$

\subsubsection{Proximate Analysis}

The moisture content was calculated by the weight lost during drying. The freezedried gelatin samples were first weighed and then placed in an oven at $105^{\circ} \mathrm{C}$ After $2 \mathrm{~h}$ of drying, the gelatin was re-weighed, then put back in the oven at $105^{\circ} \mathrm{C}$ for $1 \mathrm{~h}$, and then re-weighed again. The above operation was repeated until the difference between the two masses was less than $2 \mathrm{mg}$. The protein content of the gelatin samples was determined using the Kjeldahl method. The nitrogen conversion factor used for the gelatin was 5.55.

\subsection{Determination of Gel Strength}

The method of Fernandez-Daz et al. [24] was used to determine the gel strength. Gelatin solutions $(6.67 \%, w / v)$ were prepared at $60^{\circ} \mathrm{C}$ in distilled water and kept at $10^{\circ} \mathrm{C}$ for $16-18 \mathrm{~h}$ before analysis. The gel strength of the samples was determined by a Brookfield CT3 Texture Analyzer (Leatherhead Food Research Association Texture Analyzer Brookfield, 
USA) with a $12.7 \mathrm{~mm}$ diameter probe. The speed of the plunger was $0.5 \mathrm{~mm} / \mathrm{s}$. The maximum force was recorded when the penetration distance reached $4 \mathrm{~mm}$.

\subsection{Rheological Behavior}

The rheological behaviors of the gelatin solutions $(6.67 \%, w / v)$ were analyzed using a rheometer (AR1500ex, TA Instruments, New Castle, DE, USA) using a $40 \mathrm{~mm}$ parallel plate. Temperature sweeps were performed from 50 to $10^{\circ} \mathrm{C}$ and 10 to $50^{\circ} \mathrm{C}$ with cooling/heating rates of $1.0^{\circ} \mathrm{C} / \mathrm{min}$. The frequency and strain amplitude were set at $1 \mathrm{~Hz}$ and $0.1 \%$. The cross-over point of the storage modulus $\left(\mathrm{G}^{\prime}\right)$ and loss modulus $\left(\mathrm{G}^{\prime \prime}\right)$ was considered as the gelling or melting temperature of each gelatin gel. The angular frequency sweep of the gelatin solutions with a range of $0.1-100 \mathrm{rad} / \mathrm{s}$ were measured with a stress value of $1 \mathrm{~Pa}$. All the analyses were performed in triplicate.

\subsection{Texture Profile Analysis (TPA)}

The texture profiles of gelatin gels $(6.67 \%, w / v)$ were analyzed using the previously published method of Huang et al. [25]. A TMS-Pro Texture Analyzer (Food Technology Corporation, Sterling, VA, USA) with a $50-\mathrm{mm}$ diameter aluminum cylindrical probe $(\mathrm{P} / 50)$ was used to measure the hardness, springiness, cohesiveness, and chewiness. Each sample was poured into a mold and kept at $10{ }^{\circ} \mathrm{C}$ for $16-18 \mathrm{~h}$. The gelatin samples (d: $3 \mathrm{~cm} \times \mathrm{h}: 2.5 \mathrm{~cm}$ ) were compressed to $50 \%$ of the original height for two cycles at a speed of $60 \mathrm{~mm} / \mathrm{min}$.

\subsection{Electrophoretic Analysis}

The gelatin samples were measured as described by Laemmli et al. [26]. A gelatin solution $(1 \mathrm{mg}$ protein $/ \mathrm{mL}$ water) was mixed in a 1:4 $(\mathrm{v} / \mathrm{v})$ ratio with loading buffer (6\% $1 \mathrm{M}$ Tris-HCl, 50\% glycerol, 10\% [w/v] SDS, 1\% [w/v] bromophenol blue, and $0.5 \%$ 2-mercaptoethanol, $\mathrm{pH}$ 6.8). The mixture was heated in a boiling water bath for $5 \mathrm{~min}$. The stacking and resolving gel from the PAGE Gel Fast Preparation Kit (Shanghai epizyme Biotech Co., Ltd. Shanghai, China) was subjected to electrophoresis.

The electrophoresis was run at a constant voltage of $80 \mathrm{~V} /$ gel for the stacking gel, then run at $120 \mathrm{~V} /$ gel for $60 \mathrm{~min}$ until the resolving gel reached the bottom of the gel. This was followed by staining with Coomassie brilliant blue R-250 $(0.25 \% w / v)$. A rainbow protein maker $(5-245 \mathrm{kDa})$ was used to estimate the molecular weight distributions. The gels were scanned with an Imager 600 (Amersham, UK) gel-imaging system.

\subsection{Microstructure Analysis of Gelatin}

The microstructure of the gelatin $(6.67 \%, w / v)$ was elucidated using S-3000N cryoscanning electron microscopy (cryo-SEM, Hitachi Co., Tokyo, Japan). The samples were deposited in the slots of a stub with rivets and then frozen by plunging them into slush nitrogen. After being fractured, the free water of the gels was sublimated at $-85{ }^{\circ} \mathrm{C}$ for $30 \mathrm{~min}$, and the gel was sputter-coated with gold (Model PP3000T, Quorum Technologies, East Grinstead, UK).

\subsection{Amino Acid Composition Analysis}

The amino acid composition was measured according to GB 5009.124-2016 [27].

\subsection{Statistical Analysis}

The experiments were performed in triplicate (except for the amino acid composition data). All data underwent analysis of variance, and significant differences $(p<0.05)$ between the means were determined using Tukey's test using SPSS 17.0, SPSS Inc. (Chicago, IL, USA). 


\section{Results and Discussion}

\subsection{Yield and Proximate Composition}

The gelatin yields extracted at the three temperatures from bullfrog skin $(45,55$, and $65{ }^{\circ} \mathrm{C}$ ) are shown in Table 1 . The yields of G45, G55, and G65 were 9.6\%, $11.7 \%$, and $12.3 \%$ (on a wet weight basis), respectively. Generally, an increase in extraction temperature was associated with a higher yield. The results were consistent with those of Nagarajan et al. [22] and Kittiphattanabawon et al. [28], who reported that gelatin yield increased as the extraction temperature increased. Increasing the extract temperature provides more energy for the disruption of the stabilizing collagen structures by breaking hydrogen bonds and peptide bonds [29]. As the extraction temperature increases, gelatin undergoes more helix-to-coil transitions and becomes easier to extract into the water, leading to a higher yield [30].

Table 1. The extraction yield, proximate composition, and gelling and melting temperatures $\left({ }^{\circ} \mathrm{C}\right)$ of gelatin from bullfrog skin extracted at different temperatures.

\begin{tabular}{cccccc}
\hline Properties & PG & G45 & G55 & G65 & Bullfrog Skin \\
\hline Moisture $(\%)$ & $10.75 \pm 0.67 \mathrm{~b}$ & $6.12 \pm 0.51 \mathrm{a}$ & $7.26 \pm 0.85 \mathrm{a}$ & $6.23 \pm 1.01 \mathrm{a}$ & $67.61 \pm 0.15$ \\
Protein $(\%)$ & $87.34 \pm 0.09 \mathrm{a}$ & $87.21 \pm 0.62 \mathrm{a}$ & $87.75 \pm 0.24 \mathrm{a}$ & $87.83 \pm 0.22 \mathrm{a}$ & $19.94 \pm 0.77$ \\
Yield $(\%)$ & - & $9.63 \pm 0.28 \mathrm{a}$ & $11.69 \pm 0.25 \mathrm{~b}$ & $12.24 \pm 0.36 \mathrm{~b}$ & - \\
$\begin{array}{c}\text { Gelling } \\
\text { temperature }\left({ }^{\circ} \mathrm{C}\right)\end{array}$ & $23.9 \pm 1.7 \mathrm{a}$ & $23.4 \pm 0.4 \mathrm{a}$ & $22.8 \pm 1.4 \mathrm{a}$ & $19.3 \pm 1.4 \mathrm{a}$ & - \\
$\begin{array}{c}\text { Melting } \\
\text { temperature }\left({ }^{\circ} \mathrm{C}\right)\end{array}$ & $31.5 \pm 1.0 \mathrm{a}$ & $32.3 \pm 0.3 \mathrm{a}$ & $31.7 \pm 1.6 \mathrm{a}$ & $28.9 \pm 0.6 \mathrm{a}$ & - \\
\hline
\end{tabular}

Mean \pm SD $(n=3)$. PG: porcine gelatin. Within each row, different lowercase letters mean significant differences between different groups $(p<0.05)$.

The moisture and protein of gelatin extracted at different temperatures $(45,55$, and $65{ }^{\circ} \mathrm{C}$ from the bullfrog skin were $6.1-7.3 \%$ and $87.2-87.8 \%$, respectively. The moisture contents of all bullfrog skin gelatin samples were below the prescribed limit $(15 \%)$, which was lower than commercial porcine gelatin (PG) $(p>0.05)$. There were no significant differences in the moisture or protein contents among G45, G55, and G65. All bullfrog skin gelatin samples showed low levels of moisture content and high levels of proteins. The bullfrog skin moisture as a major component was $67.6 \%$. Zhang et al. [16] showed a similar result that the moisture content of bullfrog (Rana nigromaculata) skin was $74.0 \%$.

\subsection{Gel Strength of Gelatin}

The gel strength of the gelatins from bullfrog skin at different extraction temperatures are shown in Figure 1. G45 showed the highest gel strength (b: $272.1 \mathrm{~g})$ compared with G55 (c: $225.6 \mathrm{~g})$ and G65 (d: $205.8 \mathrm{~g}$ ) ( $p<0.05)$, which were lower than PG (a: $474.3 \mathrm{~g})$. Therefore, the extraction temperatures directly affected the gel strength of the bullfrog gelatin. This agrees with the studies by Liu et al. [31] and Sinthusamran et al. [21], who reported that high extraction temperatures significantly decreased the gel strength of gelatin.

Gelatins with different molecular weight distributions and amino acid compositions have different gel strength. Higher extraction temperatures might cause more hydrolysis, the more hydrolysis likely leads to shorter chains. The shorter chains cannot align properly, and the junction zone cannot form to a higher degree [20]. The amino acid composition has been reported to be one of the most important factors affecting the gel strength of gelatin [22]. 


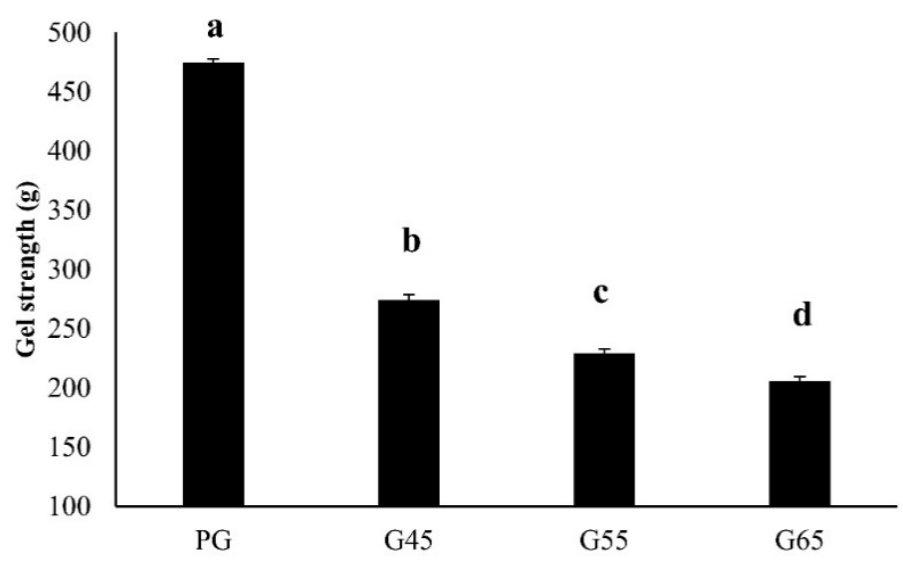

Figure 1. Gel strength of the bullfrog skin gelatin extracted at different temperatures.

\subsection{Rheological Properties}

\subsubsection{Temperature Sweep}

Figure 2 shows the temperature development of $G^{\prime}$ upon cooling and heating. $G^{\prime}$ was higher than of G" (not shown) at lower temperatures indicated that gelatin exhibited solid behavior, demonstrating gelatin molecules in a triple-helix arrangement. As shown in Figure 2, the $G^{\prime}$ of all gelatin samples increased sharply as the extraction temperature decreased, the cross-over point of $G^{\prime}$ and $G^{\prime \prime}$ (not shown) indicated that the formation of the gel was considered to be the gelling temperature of the gelatin gels.
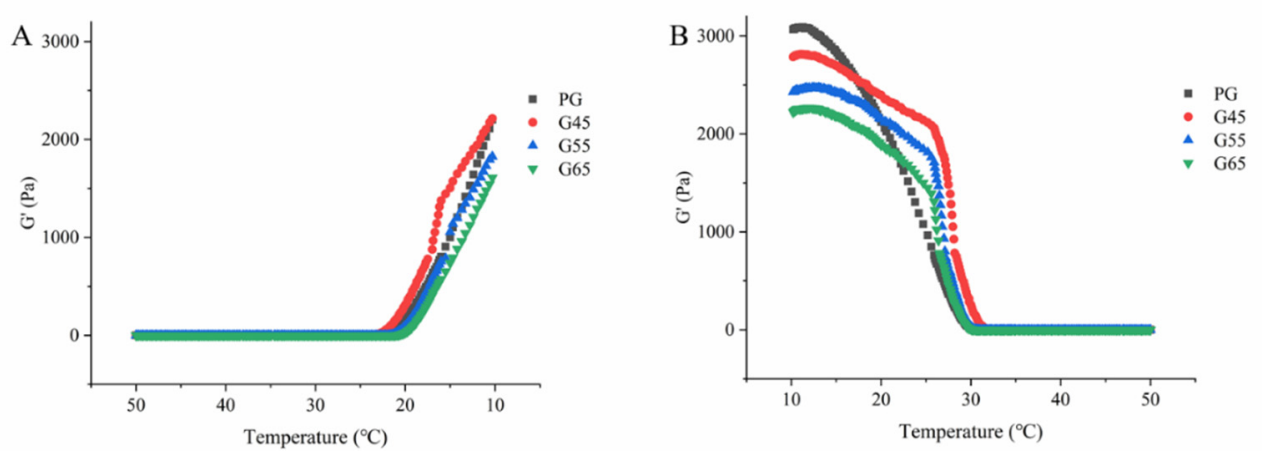

Figure 2. The storage modulus $\left(\mathrm{G}^{\prime}\right)$ of gelatin $(6.67 \%, w / v)$ from bullfrog skin extracted at different temperatures upon (A) cooling from 50 to $10{ }^{\circ} \mathrm{C}$ and subsequent (B) heating from 10 to $50{ }^{\circ} \mathrm{C}$.

The gelation process for gelatin is the transition from single strands to a triple helix via hydrogen bonding, ionic interaction, hydrophobic association, van der Waals forces, and self-assembly [32]. The maximum values of the $\mathrm{G}^{\prime}$ values of G45, G55, and G65 were 2814, 2470 , and $2266 \mathrm{~Pa}$, respectively, showing that higher temperature extraction reduced the crosslinking between gelatin molecules. This result agrees with the gel strength (Figure 1).

As shown in Table 1, the gelling and melting temperatures of G45, G55, and G65 were 19.3-23.4 ${ }^{\circ} \mathrm{C}$ and $28.9-32.3^{\circ} \mathrm{C}$, respectively, and there was no marked difference among all bullfrog skin gelatins and PG $(p>0.05)$. The gelling and melting temperatures in this study were higher than those of gelatins from the skins of camel (15.2-11.1 and $18.4-21.6{ }^{\circ} \mathrm{C}$, respectively) [9], croaker fish $\left(17.4{ }^{\circ} \mathrm{C}\right.$ and $23.8^{\circ} \mathrm{C}$, respectively) [33] and similar with goat skin gelatin (21.2-25.2 ${ }^{\circ} \mathrm{C}$ and $30.7-34.1{ }^{\circ} \mathrm{C}$, respectively) [20]. The difference in the gelling and melting properties of bullfrog gelatin compared with other gelatins can be attributed to the difference in extraction conditions, amino acid compositions, and protein chain length [29]. 


\subsubsection{Frequency Sweep}

Measuring the angular frequency of the modulus can be used to evaluate the strength of the gel network [34]. The cross-linking behavior of bullfrog skin gelatin was characterized by performing a dynamic rheological test on a $6.67 \%(w / v)$ gelatin sample at a constant temperature $\left(10^{\circ} \mathrm{C}\right.$ ) (Figure 3 ). The $\mathrm{G}^{\prime}$ values were higher than the $\mathrm{G}^{\prime \prime}$ values (not shown) during the angular frequency range studied, confirming that gelatins were capable of forming a network and possessed a solid-like gel structure at $10{ }^{\circ} \mathrm{C}$ [25]. G45 showed numerically higher $\mathrm{G}^{\prime}$ values compared with G55 and G65 (Figure 3). This observation agrees with the results of a study by Abedinia et al. [8]. As explained above, the stronger inter-molecular interactions in G45 compared with those in G55 and G65 may result in higher $\mathrm{G}^{\prime}$ values [34].

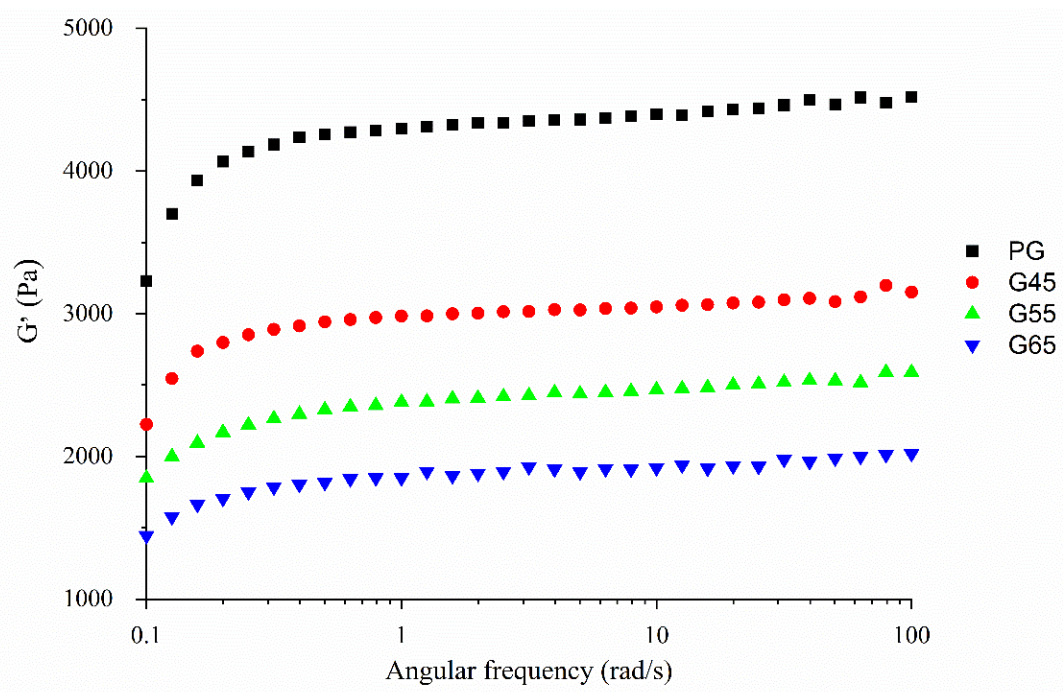

Figure 3. The storage modulus $\left(\mathrm{G}^{\prime}\right)$ of gelatin $(6.67 \%, w / v)$ from bullfrog skin extracted at different temperatures during angular frequency sweep at $10^{\circ} \mathrm{C}$.

\subsection{Texture Profile Analysis}

Texture profile analysis (TPA) is closely related to the sensory evaluation of gels [25]. The TPA results of the gelatins in this study are presented in Table 2. The hardness of G45, G55, and G65 were 28.1, 24.0, and 22.5 N, respectively. The higher extraction temperature could result in the lower hardness of gelatin gels. The hardness of all bullfrog skin gelatin was lower than porcine skin gelatin. This result is consistent with the gel strength findings (Figure 1). There were no significant differences in the springiness, cohesiveness, or chewiness among all gelatin samples $(p>0.05)$. A study reported that the textural properties of gelatin gels can be influenced by the amino acid compositions and molecular weight distributions [25].

Table 2. The texture profile analysis (TPA) parameters (hardness, springiness, cohesiveness, and chewiness) of gelatin $(6.67 \%, w / v)$ from bullfrog skin extracted at different temperatures.

\begin{tabular}{ccccc}
\hline Sample & Hardness $\mathbf{( N )}$ & $\begin{array}{c}\text { Springiness } \\
(\mathbf{m m})\end{array}$ & Cohesiveness & Chewiness (m) \\
\hline PG & $44.57 \pm 2.23 \mathrm{a}$ & $4.29 \pm 0.51 \mathrm{a}$ & $0.92 \pm 0.02 \mathrm{a}$ & $174.92 \pm 13.67 \mathrm{a}$ \\
G45 & $28.07 \pm 1.61 \mathrm{~b}$ & $5.91 \pm 0.15 \mathrm{~b}$ & $0.92 \pm 0.03 \mathrm{a}$ & $151.77 \pm 2.28 \mathrm{a}$ \\
G55 & $24.03 \pm 0.56 \mathrm{bc}$ & $6.40 \pm 0.47 \mathrm{~b}$ & $0.88 \pm 0.04 \mathrm{a}$ & $135.27 \pm 5.24 \mathrm{a}$ \\
G65 & $22.47 \pm 2.24 \mathrm{c}$ & $6.38 \pm 0.40 \mathrm{~b}$ & $0.94 \pm 0.02 \mathrm{a}$ & $135.46 \pm 19.69 \mathrm{a}$ \\
\hline
\end{tabular}

$\overline{\text { Mean } \pm \text { SD }(n=3) \text {. Within each column, different lowercase letters indicate significant differences between }}$ different groups $(p<0.05)$. 


\subsection{SDS-Polyacrylamide Gel Electrophoresis (SDS-PAGE)}

The protein patterns of the gelatin samples are shown in Figure 4. All the gelatin samples contained $\alpha$ - and $\beta$-chains with molecular weights of approximately 100 and $200 \mathrm{kDa}$, as the major components. This indicates that the $\alpha$ - and $\beta$-chains of the mother collagen were retained with rare degradation [29]. Among all the gelatin samples, G65 possessed the lowest $\alpha$ - and $\beta$-chain band intensity (as observed visually), while G45 showed a higher band intensity of $\alpha 2$-chains over G55 or G65. Gomez-Guillen et al. [35] reported that gelatins with higher $\alpha$-chain contents possessed better functional properties.

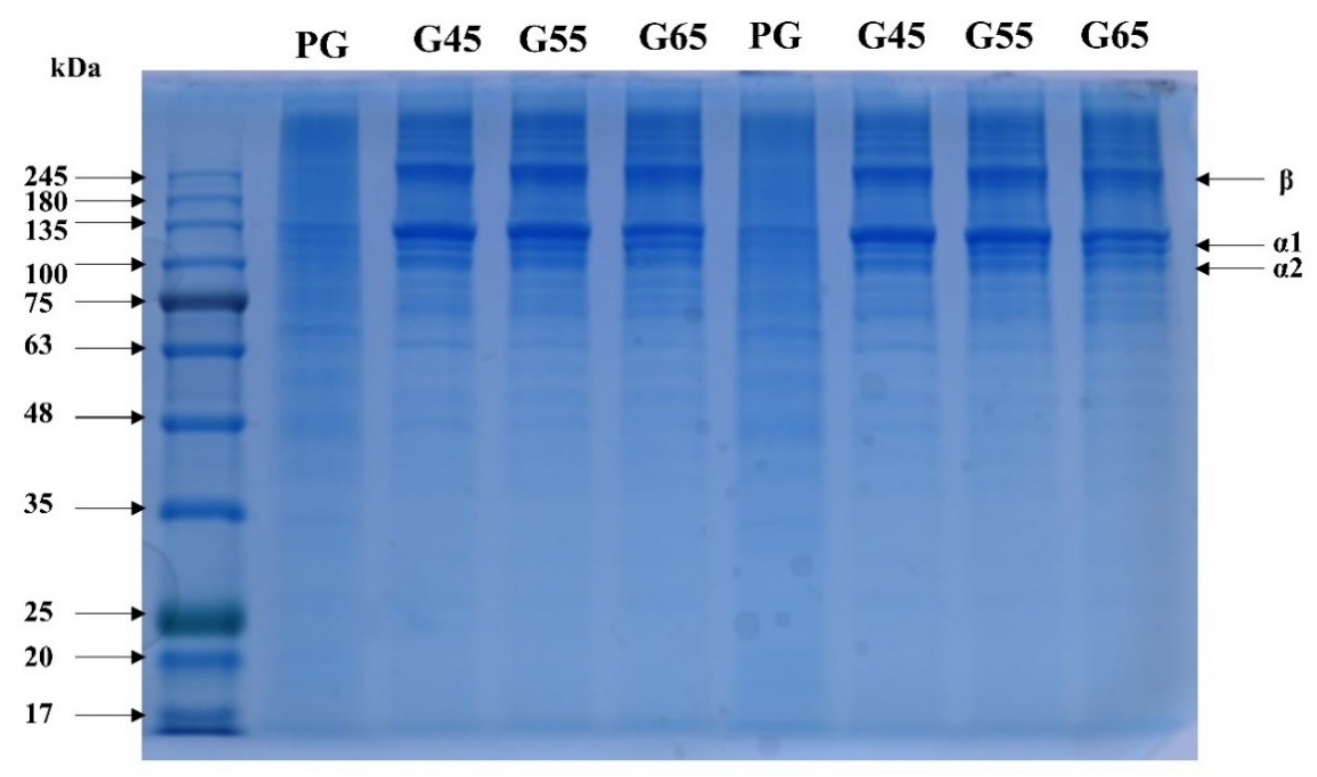

Figure 4. SDS-PAGE patterns of gelatin from bullfrog skin extracted at different temperatures.

We noted that the bands at around $70 \mathrm{kDa}$ were more intense in G65, suggesting that more drastic degradation occurred during the extraction process, which is consistent with the findings of Pang et al. [36]. It is likely that more degradation occurred in G65 as a result of the higher extraction temperature. These results suggest that the intensities of the $\alpha$ - and $\beta$-chains bands of bullfrog skin gelatin were influenced by the extraction temperature. The result was partly in accordance with Tan et al. [37], who found a high extraction temperature $\left(75^{\circ} \mathrm{C}\right)$ resulted in a decrease in the major protein components (aand $\beta$-chains) of black tilapia (Oreochromis mossambicus) gelatin.

\subsection{Microstructures of Gelatin Gels}

The gel strength of gelatin was affected by the generally conformation and association of the proteins in the gel matrix [38]. Figure 5 shows the microstructures of the gelatin gels. The structures of all gelatins were sponge or coral-like. Among all the bullfrog gelatins, G45 showed the finest gel network with very small voids. Gelatin extracted at lower temperatures with fine gel structures is consistent with a higher gel strength (Figure 1).

As observed, the gel network of G65 was found to be coarse and heterogenous. This result was partially in agreement with the findings of Sinthusamran et al. [29] who described gelatin extracted at a lower temperature for less time as having a finer gel structure. The microstructure of the gel is known to be closely related to its physical properties [36], and a heterogenous network may be more easily disrupted by applied force [28]. 

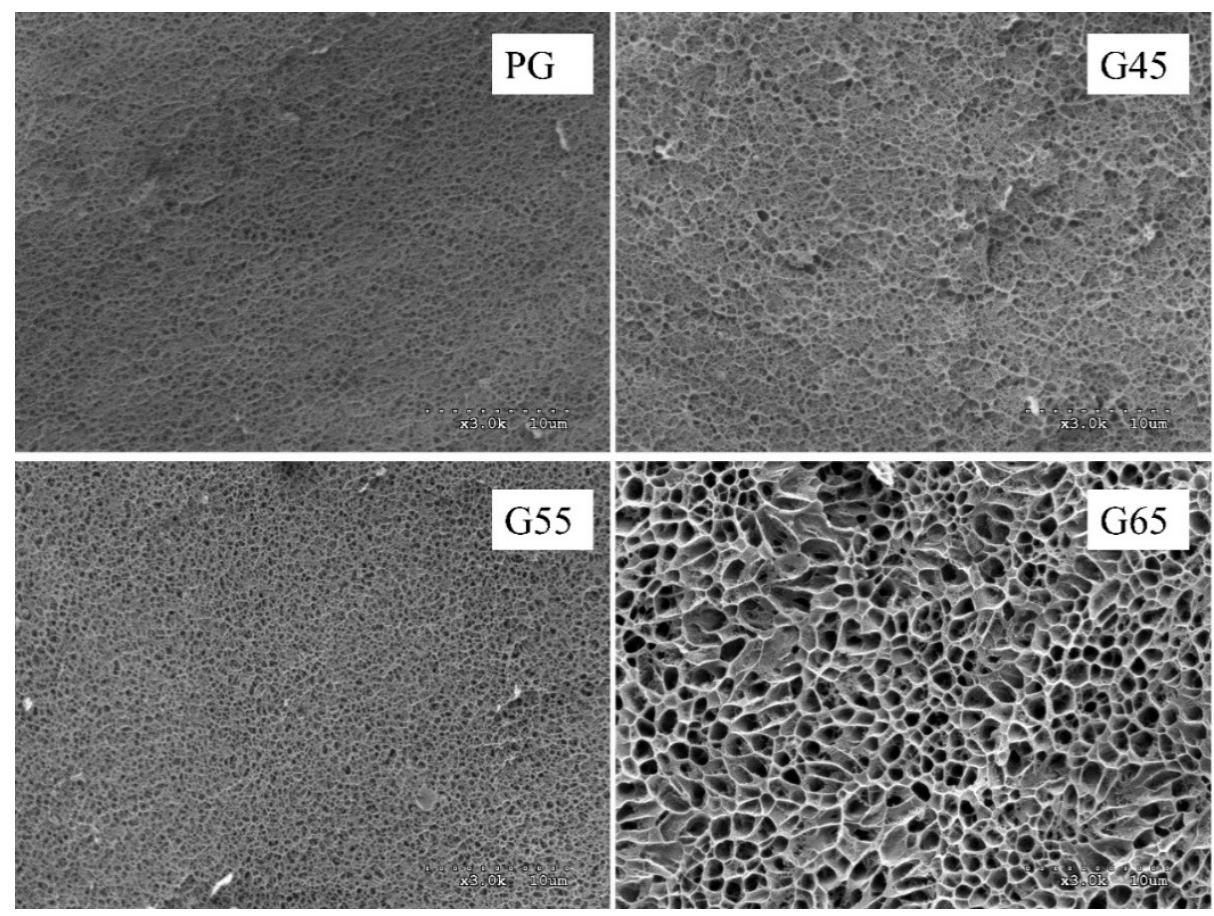

Figure 5. Microstructures of gelatin $(6.67 \%, w / v)$ from bullfrog skin extracted at different temperatures. Magnification: 3000 times.

\subsection{Amino Acid Composition}

The amino acid composition of the extracted bullfrog gelatin and PG is reported in Table 3. There were five dominant amino acids in bullfrog gelatin, including glycine (27.1-27.2\%), proline (13.4-13.6\%), glutamic acid (12.5-12.7\%), alanine (10.6-10.7\%), and arginine $(8.2-8.4 \%)$. Low contents of tyrosine $(0.4-0.5 \%)$, methionine $(0.5-0.8 \%)$, and histidine $(0.9 \%)$ were observed in all the bullfrog gelatin samples. All the bullfrog gelatins showed similar amino acid compositions. Glycine, in all the gelatin samples, represented approximately a third of the total amino acids [39]. Based on the glycine content as the major component in gelatin, the bullfrog gelatin appeared similar to porcine skin gelatin.

Table 3. The approximate amino acid composition ( $\mathrm{mg} / 100 \mathrm{mg}$ protein) of gelatins from bullfrog skin extracted at different temperatures.

\begin{tabular}{ccccc}
\hline Amino Acids (g/100 g Protein) & PG & G45 & G55 & G65 \\
\hline Aspartic acid & $5.68 \pm 0.12$ & $6.07 \pm 0.11$ & $6.14 \pm 0.03$ & $6.03 \pm 0.01$ \\
Threonine & $1.10 \pm 0.02$ & $1.55 \pm 0.09$ & $1.62 \pm 0.00$ & $1.52 \pm 0.01$ \\
Serine & $2.99 \pm 0.05$ & $4.45 \pm 0.05$ & $4.70 \pm 0.35$ & $4.40 \pm 0.01$ \\
Glutamic acid & $12.36 \pm 0.22$ & $12.71 \pm 0.02$ & $12.62 \pm 0.09$ & $12.53 \pm 0.00$ \\
Glycine & $27.46 \pm 0.62$ & $27.23 \pm 0.11$ & $27.21 \pm 0.17$ & $27.06 \pm 0.00$ \\
Alanine & $10.85 \pm 0.23$ & $10.65 \pm 0.05$ & $10.63 \pm 0.10$ & $10.59 \pm 0.01$ \\
Valine & $2.26 \pm 0.02$ & $1.42 \pm 0.01$ & $1.42 \pm 0.02$ & $1.40 \pm 0.01$ \\
Methionine & $0.69 \pm 0.01$ & $0.83 \pm 0.01$ & $0.80 \pm 0.01$ & $0.54 \pm 0.03$ \\
Isoleucine & $1.11 \pm 0.02$ & $0.98 \pm 0.01$ & $0.97 \pm 0.03$ & $0.99 \pm 0.02$ \\
Leucine & $3.32 \pm 0.09$ & $2.62 \pm 0.01$ & $2.64 \pm 0.02$ & $2.61 \pm 0.01$ \\
Tyrosine & $0.37 \pm 0.00$ & $0.47 \pm 0.02$ & $0.45 \pm 0.00$ & $0.44 \pm 0.01$ \\
Phenylalanine & $1.83 \pm 0.04$ & $1.81 \pm 0.00$ & $1.80 \pm 0.00$ & $1.79 \pm 0.04$ \\
Lysine & $3.90 \pm 0.06$ & $3.89 \pm 0.02$ & $3.86 \pm 0.00$ & $3.84 \pm 0.00$ \\
Histidine & $0.68 \pm 0.02$ & $0.90 \pm 0.00$ & $0.91 \pm 0.01$ & $0.89 \pm 0.01$ \\
Arginine & $8.24 \pm 0.02$ & $8.24 \pm 0.12$ & $8.40 \pm 0.18$ & $8.29 \pm 0.10$ \\
Proline & $14.62 \pm 0.38$ & $13.61 \pm 0.21$ & $13.43 \pm 0.33$ & $13.56 \pm 0.01$ \\
Hydrophobic acid & $20.06 \pm 0.34$ & $18.32 \pm 0.09$ & $18.25 \pm 0.12$ & $17.93 \pm 0.02$ \\
\hline
\end{tabular}


The proline content of G45 (13.6\%) was lower than in PG (14.6\%) and was higher than shark extracts (9.0\%) [14]. This result was consistent with G45 showing a lower gel strength compared with PG. Proline can form hydrogen bonds between hydroxyl groups in hydroxyproline and water molecules, and these bonds contribute to the strength of the gelatin gel [29]. The hydrophobic amino acid content of G45 (18.3\%) was lower than that of PG (20.1\%), and these amino acids can form hydrophobic associations, which also contribute to the gel strength [40]. The differences in the amino acid content might be due to the different sources and manufacturing processes of the gelatin [41].

\section{Conclusions}

The present study investigated the influence of the extraction temperature on the gel properties of bullfrog skin gelatin. Generally, the gel strength and hardness of gelatin ranged from low to moderate as the extraction temperature increased. These phenomena could be explained by the variations in the molecular weight distributions and microstructures of gelatin gels. Gelatin with a low extraction temperature showed a high $\alpha_{2}$-chain band intensity and fine gel structure, which can improve the gel properties. These results showed that American bullfrog skin has the potential to be a new source of gelatin for use in food and non-food products. A large amount of by-product from bullfrog skin could be effectively used.

Author Contributions: Conceptualization, P.W.; methodology, W.Z.; software, W.Z. and C.C.; validation, W.Z. and C.C.; formal analysis, W.Z., C.C., and Z.H.; investigation, W.Z.; resources, P.W.; data curation, W.Z. and Z.H.; writing—original draft preparation, W.Z.; writing—review and editing, P.W.; visualization, W.Z.; supervision, P.W.; project administration, P.W.; funding acquisition, P.W. All authors have read and agreed to the published version of the manuscript.

Funding: This research was supported by the National Natural Science Foundation, grant number 31901625 and 32001676.

Institutional Review Board Statement: Not applicable.

Informed Consent Statement: Not applicable.

Data Availability Statement: Data is contained within the article.

Conflicts of Interest: The authors declare no conflict of interest.

\section{References}

1. Sousa, S.C.; Vazquez, J.A.; Perez-Martin, R.I.; Carvalho, A.P.; Gomes, A.M. Valorization of By-Products from Commercial Fish Species: Extraction and Chemical Properties of Skin Gelatins. Molecules 2017, 22, 1545. [CrossRef] [PubMed]

2. Karnjanapratum, S.; Sinthusamran, S.; Sae-leaw, T.; Benjakul, S.; Kishimura, H. Characteristics and Gel Properties of Gelatin from Skin of Asian Bullfrog (Rana tigerina). Food Biophys. 2017, 12, 289-298. [CrossRef]

3. Kittiphattanabawon, P.; Benjakul, S.; Visessanguan, W.; Shahidi, F. Effect of Extraction Temperature on Functional Properties and Antioxidative Activities of Gelatin from Shark Skin. Food Bioprocess Technol. 2010, 5, 2646-2654. [CrossRef]

4. Badii, F.; Howell, N.K. Fish gelatin: Structure, gelling properties and interaction with egg albumen proteins. Food Hydrocoll. 2006, 20, 630-640. [CrossRef]

5. Aewsiri, T.; Benjakul, S.; Visessanguan, W. Functional properties of gelatin from cuttlefish (Sepia pharaonis) skin as affected by bleaching using hydrogen peroxide. Food Chem. 2009, 115, 243-249. [CrossRef]

6. Mhd Sarbon, N.; Badii, F.; Howell, N.K. Preparation and characterisation of chicken skin gelatin as an alternative to mammalian gelatin. Food Hydrocoll. 2013, 30, 143-151. [CrossRef]

7. Rafieian, F.; Keramat, J.; Shahedi, M. Physicochemical properties of gelatin extracted from chicken deboner residue. LWT Food Sci. Technol. 2015, 64, 1370-1375. [CrossRef]

8. Abedinia, A.; Ariffin, F.; Huda, N.; Mohammadi Nafchi, A. Preparation and characterization of a novel biocomposite based on duck feet gelatin as alternative to bovine gelatin. Int. J. Biol. Macromol. 2018, 109, 855-862. [CrossRef]

9. Al-Hassan, A.A. Gelatin from camel skins: Extraction and characterizations. Food Hydrocoll. 2020, 101, 105457. [CrossRef]

10. Zilhadia, Y.H.; Irwandi, J.; Effionora, A. Characterization and functional properties of gelatin extracted from goatskin. Int. Food Res. J. 2018, 25, 275-281.

11. Carvalho, A.M.; Marques, A.P.; Silva, T.H.; Reis, R.L. Evaluation of the Potential of Collagen from Codfish Skin as a Biomaterial for Biomedical Applications. Mar. Drugs 2018, 16, 495. [CrossRef] [PubMed] 
12. Renuka, V.; Rao Ravishankar, C.N.; Zynudheen, A.A.; Bindu, J.; Joseph, T.C. Characterization of gelatin obtained from unicorn leatherjacket (Aluterus monoceros) and reef cod (Epinephelus diacanthus) skins. LWT 2019, 116, 108586. [CrossRef]

13. Fan, H.; Dumont, M.J.; Simpson, B.K. Extraction of gelatin from salmon (Salmo salar) fish skin using trypsin-aided process: Optimization by Plackett-Burman and response surface methodological approaches. J. Food Sci. Technol. 2017, 54, 4000-4008. [CrossRef] [PubMed]

14. Seixas, M.J.; Martins, E.; Reis, R.L.; Silva, T.H. Extraction and Characterization of Collagen from Elasmobranch Byproducts for Potential Biomaterial Use. Mar. Drugs 2020, 18, 617. [CrossRef]

15. Zhang, C.-x.; Huang, K.-k.; Wang, L.; Song, K.; Zhang, L.; Li, P. Apparent digestibility coefficients and amino acid availability of common protein ingredients in the diets of bullfrog, Rana (Lithobates) catesbeiana. Aquaculture 2015, 437, 38-45. [CrossRef]

16. Zhang, J.; Duan, R. Characterisation of acid-soluble and pepsin-solubilised collagen from frog (Rana nigromaculata) skin. Int. J. Biol. Macromol. 2017, 101, 638-642. [CrossRef]

17. Aksun Tumerkan, E.T.; Cansu, U.; Boran, G.; Regenstein, J.M.; Ozogul, F. Physiochemical and functional properties of gelatin obtained from tuna, frog and chicken skins. Food Chem. 2019, 287, 273-279. [CrossRef]

18. Pasteris, S.E.; Bühler, M.I.; Nader-Macías, M.E. Microbiological and histological studies of farmed-bullfrog (Rana catesbeiana) tissues displaying red-leg syndrome. Aquaculture 2006, 251, 11-18. [CrossRef]

19. Pasteris, S.E.; Vera Pingitore, E.; Roig Babot, G.; Otero, M.C.; Buhler, M.I.; Nader-Macias, M.E. Characterization of the beneficial properties of lactobacilli isolated from bullfrog (Rana catesbeiana) hatchery. Antonie Van Leeuwenhoek 2009, 95, 373-385. [CrossRef] [PubMed]

20. Mad-Ali, S.; Benjakul, S.; Prodpran, T.; Maqsood, S. Characteristics and Gel Properties of Gelatin from Goat Skin as Affected by Extraction Conditions. J. Food Process Preserv. 2017, 41, e12949. [CrossRef]

21. Sinthusamran, S.; Benjakul, S.; Hemar, Y.; Kishimura, H. Characteristics and Properties of Gelatin from Seabass (Lates calcarifer) Swim Bladder: Impact of Extraction Temperatures. Waste Biomass Valori. 2016, 9, 315-325. [CrossRef]

22. Nagarajan, M.; Benjakul, S.; Prodpran, T.; Songtipya, P.; Kishimura, H. Characteristics and functional properties of gelatin from splendid squid (Loligo formosana) skin as affected by extraction temperatures. Food Hydrocoll. 2012, 29, 389-397. [CrossRef]

23. Hafsteinsson, M.G.H. Gelatin from cod skins as affected by chemical treatments. J. Food Sci. 1997, 62, 37.

24. Fernandez-Daz, M.D.M.P.; Gomez-Guillen, M.C. Gel properties of collagens from skins of cod (Gadus morhua) and hake (Merluccius merluccius) and their modification by the coenhancers magnesium sulphate, glycerol and transglutaminase. Food Chem. 2001, 74, 161-167. [CrossRef]

25. Huang, T.; Tu, Z.C.; Shangguan, X.; Wang, H.; Sha, X.; Bansal, N. Rheological behavior, emulsifying properties and structural characterization of phosphorylated fish gelatin. Food Chem. 2018, 246, 428-436. [CrossRef] [PubMed]

26. Laemmli, U.K. Cleavage of Structural Proteins during the Assembly of the Head of Bacteriophage T4. Nature 1970, 227, 680-685. [CrossRef]

27. GB5009.124-2016, National standards of the People's Republic of China. In Determination of Amino Acids in Foods (2016); National Health and Family Planning Commission of the People's Republic of China: China, 2016.

28. Kittiphattanabawon, P.; Benjakul, S.; Visessanguan, W.; Shahidi, F. Comparative study on characteristics of gelatin from the skins of brownbanded bamboo shark and blacktip shark as affected by extraction conditions. Food Hydrocoll. 2010, 24, 164-171. [CrossRef]

29. Sinthusamran, S.; Benjakul, S.; Kishimura, H. Characteristics and gel properties of gelatin from skin of seabass (Lates calcarifer) as influenced by extraction conditions. Food Chem. 2014, 152, 276-284. [CrossRef]

30. Kaewruang, P.; Benjakul, S.; Prodpran, T. Molecular and functional properties of gelatin from the skin of unicorn leatherjacket as affected by extracting temperatures. Food Chem. 2013, 138, 1431-1437. [CrossRef]

31. Liu, Y.; Xia, L.; Jia, H.; Li, Q.; Jin, W.; Dong, X.; Pan, J. Physiochemical and functional properties of chum salmon (Oncorhynchus keta) skin gelatin extracted at different temperatures. J. Sci. Food Agric. 2017, 97, 5406-5413. [CrossRef]

32. Silva, M.A.D.; Bode, F.; Grillo, I.; Dreiss, C.A. Exploring the kinetics of gelation and final architecture of enzymatically cross-linked chitosan/gelatin gels. Biomacromolecules 2015, 16, 1401-1409. [CrossRef]

33. Kumar, D.P.; Chandra, M.V.; Elavarasan, K.; Shamasundar, B.A. Structural properties of gelatin extracted from croaker fish (Johnius sp.) skin waste. Int. J. Food Prop. 2018, 20, S2612-S2625. [CrossRef]

34. Abedinia, A.; Ariffin, F.; Huda, N.; Nafchi, A.M. Extraction and characterization of gelatin from the feet of Pekin duck (Anas platyrhynchos domestica) as affected by acid, alkaline, and enzyme pretreatment. Int. J. Biol. Macromol. 2017, 98, 586-594. [CrossRef]

35. Gomez-Guillen, M.C.; Turnay, J.; Fernandez-Diaz, M.D. Structural and physical properties of gelatin extracted from different marine species a comparative study. Food Hydrocoll. 2002, 16, 25-34. [CrossRef]

36. Pang, Z.; Deeth, H.; Sopade, P.; Sharma, R.; Bansal, N. Rheology, texture and microstructure of gelatin gels with and without milk proteins. Food Hydrocoll. 2014, 35, 484-493. [CrossRef]

37. Tan, C.-C.; Karim, A.A.; Uthumporn, U.; Ghazali, F.C. Effect of Extraction Temperature on the Physicochemical Properties of Gelatine from the Skin of Black Tilapia (Oreochromis mossambicus). J. Phys. Sci. 2019, 30, 1-21. [CrossRef]

38. Benjakul, S.; Oungbho, K.; Visessanguan, W.; Thiansilakul, Y.; Roytrakul, S. Characteristics of gelatin from the skins of bigeye snapper, Priacanthus tayenus and Priacanthus macracanthus. Food Chem. 2009, 116, 445-451. [CrossRef] 
39. Binsi, P.K.; Shamasundar, B.A.; Dileep, A.O.; Badii, F.; Howell, N.K. Rheological and functional properties of gelatin from the skin of bigeye snapperr (Priacanthus hamrur) fish Influence of gelatin on the gel-forming ability of fish mince. Food Hydrocoll. 2009, 23, 132-145. [CrossRef]

40. Chiesa, E.; Pisani, S.; Colzani, B.; Dorati, R.; Conti, B.; Modena, T.; Braekmans, K.; Genta, I. Intra-Articular Formulation of GE11-PLGA Conjugate-Based NPs for Dexamethasone Selective Targeting-In Vitro Evaluation. Int. J. Mol. Sci. 2018, 19, 2304. [CrossRef]

41. Duconseille, A.; Astruc, T.; Quintana, N.; Meersman, F.; Sante-Lhoutellier, V. Gelatin structure and composition linked to hard capsule dissolution: A review. Food Hydrocoll. 2015, 43, 360-376. [CrossRef] 